\title{
Spatial Distribution of Carbonaceous Aerosol in the Southeastern Baltic Sea Region (Event of Grass Fires)
}

\author{
Vadimas DUDOITIS ${ }^{1}$, Steigvilè BYČENKIENE ${ }^{1}$, Kristina PLAUŠKAITÉ ${ }^{1}$, \\ Carlo BOZZETTI ${ }^{2}$, Roman FRÖHLICH ${ }^{2}$, Genrik MORDAS ${ }^{1}$, \\ and Vidmantas ULEVIČIUS ${ }^{1}$
}

\author{
${ }^{1}$ SRI Center for Physical Sciences and Technology, Vilnius, Lithuania; \\ e-mails: steigvile.bycenkiene@ftmc.lt (corresponding author), ulevicv@ktl.mii.lt \\ ${ }^{2}$ Laboratory of Atmospheric Chemistry, Paul Scherrer Institute (PSI), \\ Villigen, Switzerland
}

\begin{abstract}
The aerosol chemical composition in air masses affected by large vegetation fires transported from the Kaliningrad region (Russia) and southeast regions (Belarus and Ukraine) during early spring (March 2014) was characterized at the remote background site of Preila, Lithuania. In this study, the chemical composition of the particulate matter was studied by high temporal resolution instruments, including an Aerosol Chemical Speciation Monitor (ACSM) and a seven-wavelength aethalometer. Air masses were transported from twenty to several hundred kilometres, arriving at the measurement station after approximately half a day of transport. The concentration-weighted trajectory analysis suggests that organic aerosol particles are mainly transported over the Baltic Sea and the continent (southeast of Belarus). Results show that a significant fraction of the vegetation burning organic aerosol is transformed into oxidised forms in less than a half-day. Biomass burning aerosol (BBOA) was quantified from the ACSM data using a positive matrix factorization (PMF) analysis, while its spatial distribution was evaluated using air mass clustering approach.
\end{abstract}

Key words: ACSM, air masses, organic aerosol, nitrate and sulphate, ammonium and chloride. 


\section{INTRODUCTION}

Carbonaceous aerosols (organic aerosol (OA) and black carbon (BC)) have received more attention in recent years for their impacts on visibility degradation (BC is a major component affecting light absorption), influence on radiative forcing, climate, and human health (Mauderly and Chow 2008, IPCC 2013). The main sources of carbonaceous aerosols are biomass and fossil fuel burning, and the atmospheric oxidation of gas-phase biogenic and anthropogenic volatile organic compounds (VOCs) (Bond et al. 2013, IPCC 2013). Both, organic carbon (OC) and BC, have different optical and chemical properties and thus exert different impact on atmospheric composition and climate. In Europe, the carbonaceous aerosol is a major fraction of the particulate matter at rural background sites (Yttri et al. 2007). Inorganic aerosol constituents, such as sulphate $\left(\mathrm{SO}_{4}{ }^{-2}\right)$, nitrate $\left(\mathrm{NO}_{3}{ }^{-}\right)$, ammonium $\left(\mathrm{NH}_{4}^{+}\right)$, and chloride $\left(\mathrm{Cl}^{-}\right)$, can also be major components of aerosol, depending on location and time of the year (Dall'Osto et al. 2014).

Most of source apportionment studies cannot provide information about geographical location of sources or the effect of polluted regions downwind of receptor site. Source apportionment results are frequently supplemented by procedures to identify the direction of air masses associated with high pollution levels or where compounds of interest come from (Rizzo and Scheff 2007, Gildemeister et al. 2007, Du and Rodenburg 2007). For small scales this can be done by wind rose analysis; on the other hand, long-range transport may be better evaluated using air mass backward trajectories model (Draxler and Rolph 2014). The knowledge of long-range transport origin and contribution to pollution level can help understanding the sources of local air pollution at a given location and formulate optimal abatement strategies. Most Northern Europe sites still face this problem, since this region is particularly affected by air pollution from the industrialized surrounding regions from the Southern Europe continent (Byčenkienè et al. 2014, Beverland et al. 2000, Abdalmogith and Harrison 2005). Moreover, smoke from large vegetation burning fires in Kaliningrad and European part of Russia often affects air quality in all neighbouring northern countries (Sillanpää et al. 2005, Ovadnevaite et al. 2006, Saarikoski et al. 2007). For the interpretation of source areas, the concentration weighted trajectory (CWT) analysis has been used (Hoh and Hites 2004, Salvador et al. 2004). In March 2014, Preila encountered the highest BC and PM10 pollution with a maximum hourly concentration of 13.6 and $140 \mu \mathrm{g} \mathrm{m}^{-3}$, respectively, arousing public attention to pollution levels (http://oras.gamta.1t/files/Oras_140310v.pdf). The main type of biomass burning in Lithuania and surrounding countries in early spring is biomass burning for heating purposes and illegal last year's grass burning for "land clearing" (Ulevičius et al. 2010, Byčenkienè et al. 2013). 
In this paper, a backward trajectories modelling approach was used to understand the spatial distribution of pollutant transport pathways and to identify the potential source regions to the observed spring $\mathrm{OA}$ and $\mathrm{BC}$ at Preila during springtime over South-Eastern Baltic region. Meanwhile, different transport patterns may influence a certain air pollution episode, so air mass clustering results were analysed to reveal the dominant transport pathways that correspond to elevated pollutant concentrations.

\section{METHODS}

\subsection{Sampling site}

Air sampling was carried out at the Atmospheric Research Station located at Preila (Lithuania) (latitude $55^{\circ} 55^{\prime} \mathrm{N}$ and longitude $21^{\circ} 04^{\prime} \mathrm{E}$ ) from 1 to 31 March 2014 (Section 3.1, Fig. 1A). The sampling site is representative of a large rural area in South-Eastern Baltic region. It is a characteristic place for evaluating the influence of spring grassland fires on air quality which are important ecological and cultural phenomena in Baltic countries. The site is approximately $200 \mathrm{~m}$ away from the seaside. Long-range transported air pollution has a major influence on the local air quality as well, especially during the occurrence of biomass burning episodes. A severe biomass/vegetation burning episodes were experienced in Preila on 7-11 March 2014 due to uncontrolled vegetation fires in Kaliningrad (Section 3.1, Fig. 1B, C).

\subsection{Instrumentation}

An Aerodyne Research, Inc. (Billerica, MA, US, 01821-3976) Aerosol Chemical Speciation Monitor ( $\mathrm{Ng}$ et al. 2011) was deployed at Preila site (Fig. 1) for the purpose of measuring PM1 real-time $\mathrm{Cl}^{-}, \mathrm{NH}_{4}{ }^{+}, \mathrm{NO}_{3}{ }^{-}$, and $\mathrm{SO}_{4}{ }^{2-}$. A PM10 impactor-inlet (selfdesigned) was applied in front of the sampling line to remove coarse particles. The residence time in the sampling tube is $\sim 2.65 \mathrm{~s}$. The particle transport losses were smaller than $2 \%$. The resulting aerosol flow passed through a Nafion dryer (MD-110-48S-4, PermaPure LLC, Toms River, NJ, USA) and $\sim 2.5 \mathrm{~m}$ long stainless steel sampling tube $(6 \mathrm{~mm}$ i.d.) before reaching the ACSM inlet. During this study, the ACSM was operated at a time resolution of $\sim 28$ min for typical aerosol loadings (several $\mu \mathrm{g} \mathrm{m}^{-3}$ loadings) with a scan rate of mass spectrometer at $220 \mathrm{~ms} \mathrm{amu}^{-1}$ from m/z 10 to 140 (approx. $31.9 \mathrm{~s}$ per scan and $1.126 \mathrm{~s}$ pause, 56 scans and data interval of $29 \mathrm{~min} 48 \mathrm{~s}$ ). The determined calibration parameters were: response factor (RF) $\mathrm{RFNO}_{3}=2.75 \times 10^{-11}$, and relative ionization efficiency (RIE) $\mathrm{RIENH}_{4}=6.16, \mathrm{RIESO}_{4}=0.92$. The detailed description of ACSM has been given in Ng et al. (2011). We used a Nafion dryer to dry ambient air samples to keep $\mathrm{RH}<50 \%$. The determined collection efficiency was around 0.5 . 
A Magee Scientific Company aethalometer ${ }^{\mathrm{TM}}$, Model AE31 Spectrum, manufactured by Aerosol d.o.o., Ljubljana, Slovenia, was deployed at the site and provided real-time, continuous measurements of the $\mathrm{BC}$ mass concentration. The optical transmission of carbonaceous aerosol particles was measured sequentially at seven wavelengths $\lambda(370,450,520,590,660,880$, and $950 \mathrm{~nm}$ ). The concentration of black carbon corresponds to the $880 \mathrm{~nm}$ wavelength. The aethalometer data were recorded with 20 -minute time resolution and averaged to $1 \mathrm{~h}$. Concentration was compensated for loading effects using an empirical algorithm (Virkkula et al. 2007). The aethalometer was equipped with PM2.5 impactor.

A Scanning Mobility Particle Sizer (SMPS) system was used to measure the dry particle number size distribution in the size range of 9-840 nm (mobility diameter). The system consists of one neutralizer $(241 \mathrm{Pu})$, one Differential Mobility Analyser (DMA) (Leibniz Institute for Tropospheric Research), one Condensation Particle Counter (CPC UF-02), a control unit, and data logging system. A scan time of $180 \mathrm{~s}$ and retrace time of $120 \mathrm{~s}$ was employed for each sample. The sheath flow within the system is $51 / \mathrm{min}$, the sample flow rate $1 \mathrm{l} / \mathrm{min}$. The aerosol particle number concentration (PNC) values were measured at 1-min intervals and the particle size distribution determined at 5-min intervals which are then re-averaged to 1-h average. The relative humidity throughout the system was kept below $40 \%$.

\subsection{Satellite products}

Dust and grass burning smoke plume layers were evaluated by the CloudAerosol Lidar and Infrared Pathfinder Satellite Observation (CALIPSO) Level-2 aerosol products (Version 3.01).

\subsection{Air mass trajectory clustering}

HYSPLIT 4 (HYbrid Single-Particle Lagrangian Integrated Trajectory) trajectories (Draxler and Rolph 2014) were calculated for an arrival height of $10 \mathrm{~m}$ above ground level at 3-h intervals, going $72 \mathrm{~h}$ back in time. In order to analyze the association between trajectories and observed concentrations measured at Preila site, air mass backward trajectory cluster analysis was used to classify trajectories into groups (clusters) of similar history, i.e., similar path of advection and velocity of air flow, meaning that the errors in the individual trajectories tend to average out. A non-hierarchical clustering algorithm was used in this study. To calculate the CWT, the whole geographic region covered by the 72-h backward trajectories was divided into a gridded $i$ by $j$ array. In this study, based on the maximum distance traveled by the air mass back trajectories over the study period, the grid covers an area of interest defined by $(40-70) \mathrm{N}$ and $20 \mathrm{~W}-40 \mathrm{E}$ with the center of Preila site $\left(55.55^{\circ} \mathrm{N}, 21.04^{\circ} \mathrm{E}\right)$ as the midpoint, and containing grid cells of $0.2^{\circ} \times 0.2^{\circ}$. 
The CWT is a measure of the source strength of a grid cell and is determined as follows (Kabashnikov et al. 2011, Jeong et al. 2011):

$$
C W T_{i, j}=\sum_{T=1}^{L} C_{T} \tau_{i, j, T} / \sum_{T=1}^{L} \tau_{i, j, T},
$$

where $C_{T}$ is the 1-h BC concentration corresponding to the arrival of back trajectory $T, \tau_{i, j, T}$ is the number of trajectory segment endpoints in a grid cell $(i, j)$ for back trajectory $T$ divided by the total number of trajectory segment endpoints for back trajectory $T$, and $L$ is the total number of back trajectories over a time period.

\section{RESULTS}

\subsection{Concentrations and chemical composition of submicron aerosols}

The biomass fires took place in an approximate radius of 25 to $300 \mathrm{~km}$ from Preila measurement site (Fig. 1A). Laboratory experiments have shown that

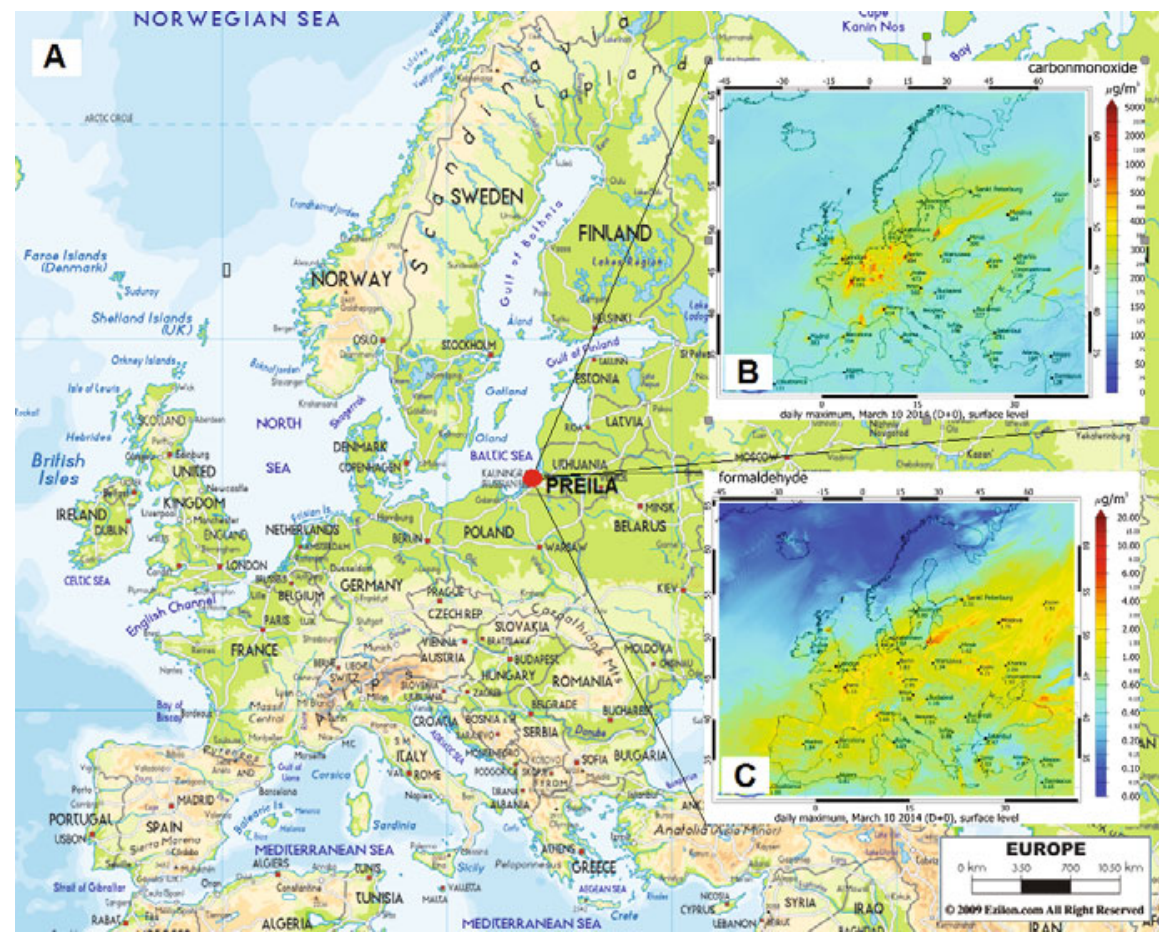

Fig. 1: (A) Map of the observation site, Preila (red marker), which is at a distance of about $40 \mathrm{~km}$ to the south (Klaipeda), and $90 \mathrm{~km}$ to the north to other major city, Kaliningrad (Russia); (B and C) concentrations of CO and formaldehyde at extended European grid analysed joining the chemistry transport model, satellite products, and in situ observations. The algorithm is the three-dimensional variational (3D-var) method which allows for a better linear unbiased estimate. 

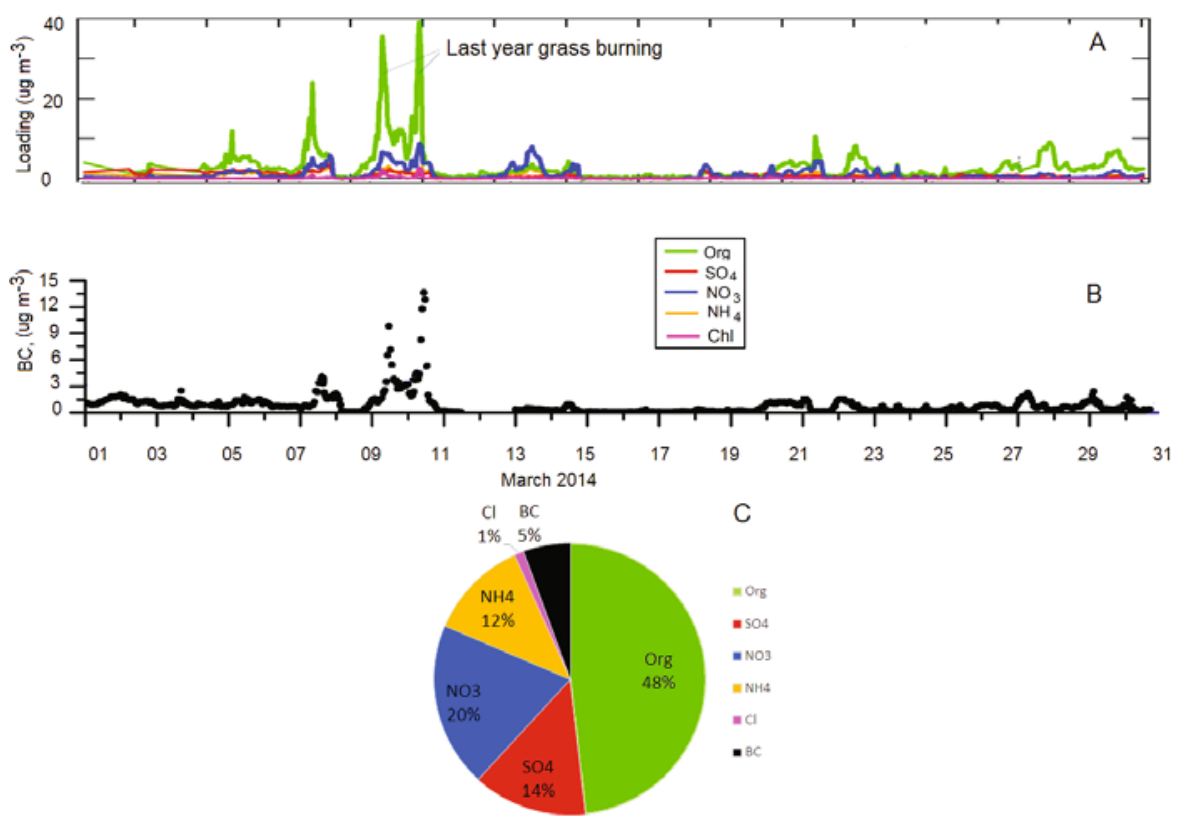

Fig. 2. Time trends of non-refractory submicron aerosol species measured with: (A) the ACSM, and (B) BC concentration in March 2014; (C) relative contribution of NR-PM1 chemical species. Color scheme in panels (A) and (B) is identical to (C).

emissions of formaldehyde during biomass burning are strongly correlated with the emissions of CO and formaldehyde (Goode et al. 1999) (Fig. 1B, C).

The ACSM ran continuously for 4 weeks with a 28 min sampling time interval. The data were online automatically uploaded to an FTP site each time a new file was written.

Figure 2 shows the time series of organics, $\mathrm{SO}_{4}{ }^{2-}, \mathrm{NO}_{3}{ }^{-}, \mathrm{NH}_{4}{ }^{+}$, and $\mathrm{Cl}^{-}$, as well as the average mass fraction of each species measured by the ACSM. The ACSM data were analysed with the standard ACSM data analysis software (Igor Pro, WaveMetrics, Inc., Oregon, USA). Vegetation burning events were identified by an extremely enhanced BC concentration $\left(\sim 12 \mu \mathrm{g} \mathrm{m}^{-3}\right)$. We assume that $750 \mathrm{ng} \mathrm{m}^{-3}$ corresponds to the annual mean concentration for Preila during periods where the site is not affected by biomass burning. This limit is a little higher as compared to average background levels reported for European background sites (Van Dingenen et al. 2004, Putaud et al. 2004, 2010).

\subsection{Relationships between air mass history and source apportionment}

The 72-h backward trajectories of air masses arriving at Preila in March 2014 were categorized by $k$-means clustering into six clusters. Six clusters 

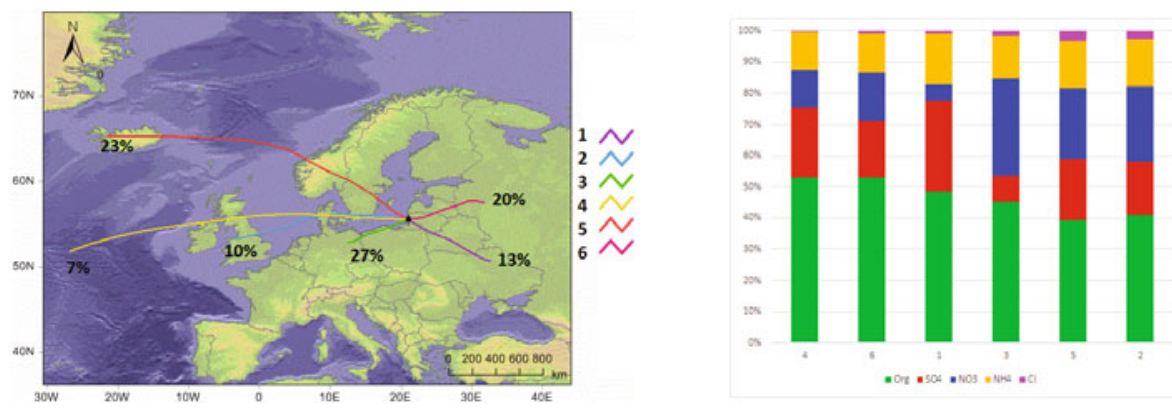

Fig. 3. The percentual contribution of back-trajectories cluster during measurement period.

by their representative trajectories are shown in Fig. 3, along with the corresponding average $\mathrm{BC}$ concentration associated with each cluster. Based on the analysis of the whole trajectory data set, the most frequently arriving directions were southwest (cluster 3, 27\%) and west-northwest (cluster 5, $23 \%$ ), followed by north-east (cluster 6, 20\%), south-east (cluster 1, 13\%), west (cluster 2, 10\%) and west-southwest (cluster 4, 7\%).

The length of the cluster-mean air mass backward trajectories indicates the transport speed of air masses, so it is seen from Fig. 3 that the trajectories of air masses from the directions of west and the northwest (clusters 2, 4, and 5) were longer and the masses moved faster, while trajectories in clusters 1,3 , and 6 were shorter and the masses moved much slower. Mean organic aerosol, nitrate, sulphate, ammonium, chloride, and BC concentrations for each cluster are presented in Table 1.

The most polluted clusters, 1 and 4, represent polluted transport pathway for organic aerosol. This is presumably due to the fact that there are relative-

Table 1

Mean concentration of organic aerosol, nitrate, sulphate, ammonium, chloride, and $\mathrm{BC}$ for each cluster

\begin{tabular}{|c|c|c|c|c|c|c|}
\hline Clusters & $\begin{array}{c}\text { Org. } \\
{\left[\mu \mathrm{g} \mathrm{m}^{-3}\right]}\end{array}$ & $\begin{array}{c}\mathrm{SO}_{4} \\
{\left[\mu \mathrm{g} \mathrm{m}^{-3}\right]}\end{array}$ & $\begin{array}{c}\mathrm{NO}_{3} \\
{\left[\mu \mathrm{g} \mathrm{m}^{-3}\right]}\end{array}$ & $\begin{array}{c}\mathrm{NH}_{4} \\
{\left[\mu \mathrm{g} \mathrm{m}^{-3}\right]}\end{array}$ & $\begin{array}{c}\mathrm{Cl} \\
{\left[\mu \mathrm{g} \mathrm{m}^{-3}\right]}\end{array}$ & $\begin{array}{c}\mathrm{BC} \\
{\left[\mathrm{ng} \mathrm{m}^{-3}\right]}\end{array}$ \\
\hline 1 & 4.47 & 1.125 & 0.28 & 0.84 & 0.12 & 1290 \\
2 & 2.82 & 0.455 & 0.55 & 0.67 & 0.09 & 510 \\
3 & 1.65 & 0.6 & 1.62 & 0.52 & 0.11 & 500 \\
4 & 3.41 & 1.11 & 0.71 & 0.64 & 0.03 & 252 \\
5 & 0.80 & 0.36 & 0.63 & 0.15 & 0.04 & 80 \\
6 & 2.31 & 0.56 & 0.77 & 0.68 & 0.12 & 600 \\
\hline Mean & 2.13 & 0.78 & 0.86 & 0.61 & 0.06 & 823 \\
\hline
\end{tabular}


ly strong biomass burning emission sources in the areas of Kaliningrad and Belarus, which are located such that for an air parcel passing over them, on average, it takes about 1-2 days to arrive in Preila.

CALIPSO lidar data also confirmed the presence of a smoke plume over the biomass burning area on 10 March. Biomass burning aerosols have higher absorption at $532 \mathrm{~nm}$ (Labonne et al. 2007). This provides an informal method to separate biomass burning aerosol and cloud layers. The plume of smoke observed over this area was mostly generated by active fires of the same day captured over an area with many fires during the time period studied. The CALIPSO Level-2 attenuated backscatter coefficients are imaged in Fig. 4A. As shown in Fig. 4A, no layer of clouds appeared along the CALIPSO path during the grass burning event, indicating a strong attenuated backscatter of an aerosol layer. It is also consistent with the modelling results showing large smoke concentrations over this region.

Figure 4 depicts the depolarization (panel B) and aerosol type classification (panel C) (CALIPSO high-resolution vertical profiles of aerosol). The depolarization ratio of clouds (6.5-9.0) differs considerably from grass burning aerosol (1.5 to 3.5), enabling separation of these two types. Blue colours correspond to molecular scattering and weak aerosol scattering; aerosols generally show up as yellow-to-red shades. Strong cloud signals are plotted in grey. Near the ground, the areas of high backscatter (red, orange, pink) are aerosol layers, although bright pink and white areas (at 10-15 km altitude) indicate cirrus clouds. The level 1 aerosol subtitle product was used to identify grass burning plume composition and height (Amiridis et al. 2010). The grass burning smoke plume layer (brown) is indicated at $\sim 1 \mathrm{~km}$ along the latitude of $54-46^{\circ} \mathrm{N}$ (identified by the backscatter ratio $R$ is $>1.06$ ). This threshold is identical to the one used for aerosol classification with the Esrange lidar (Blum et al. 2005).

So, it is evident that the air masses associated with these clusters originated from the biomass burning areas, indicating that it is an important transport pathway, determined high concentrations at the Preila site. It should be noted that the trajectory in cluster 4 is one of shorter within all the six clusters, indicating the accumulation of pollutants arrived from open vegetation burning. Cluster 1 represents the second most polluted transport pathways and its centration was related to the southeast pathways (Belarus and Ukraine). Along such pathways the high biomass burning emissions were located, which was indicated by high CWT values. The average BC concentrations for clusters 4 and 5 were the lowest, indicating that the pathway from the west is relatively cleaner than that from the continent.

To investigate the primary organic aerosol (POA) distribution over study area positive matrix factorization (PMF) (Paatero 1997) and potential source contribution function (PSCF) analysis were applied (Fig. 5). 


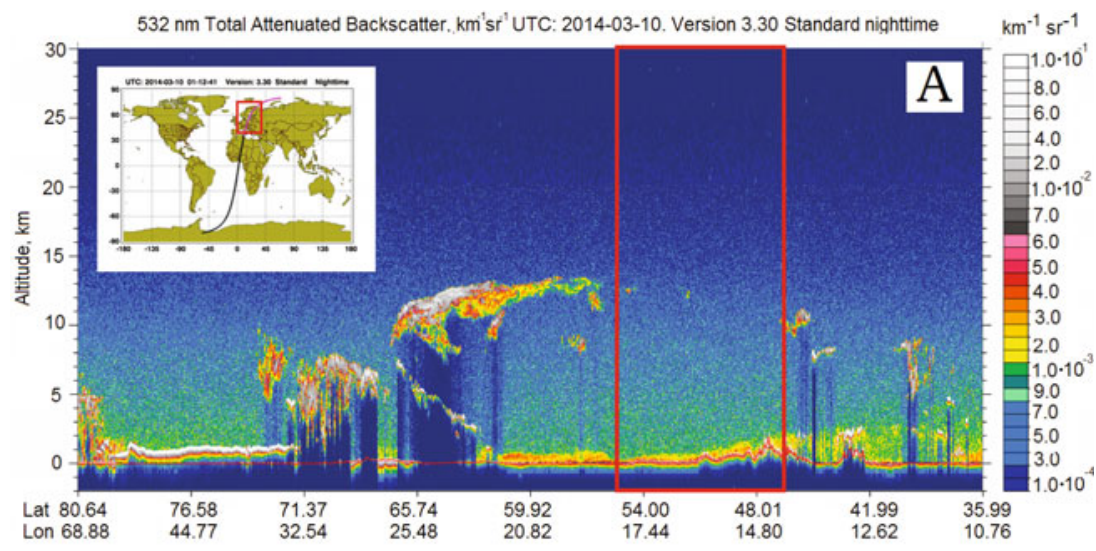

Depolarization ratio UTC: 2014-03-10. Version 3.30 Standard nighttime
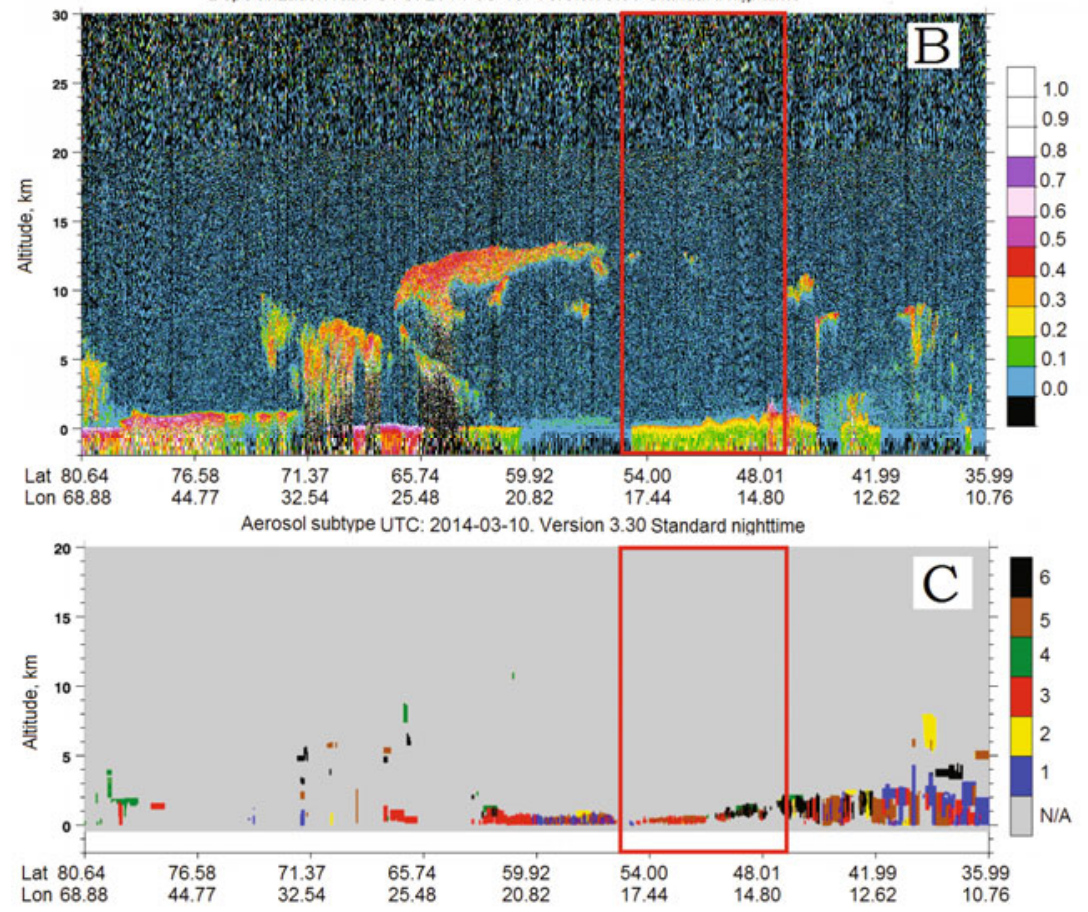

$\mathrm{N} / \mathrm{A}=$ not applicable $1=$ clean marine $2=$ dust $3=$ polluted continental $4=$ clean continental $5=$ polluted dust $6=$ smoke

Fig. 4: (A) Total attenuated backscatter at $532 \mathrm{~nm}$ along with the orbit track embedded in the upper left (in $\mathrm{km}^{-1} \mathrm{sr}^{-1}$ ). The line in red represents the closest approach to the region of biomass burning area on 10 March 2014 (the colour bars for attenuated backscatter show the colours assigned to ranges of attenuated backscatter (in $\mathrm{km}^{-1} \mathrm{sr}^{-1}$ ); the vertical axes are annotated to indicate altitude in kilometres, the horizontal axes are annotated with latitude in kilometres (in deg) and longitude (in deg); (B) depolarization ratio; (C) vertical feature mask (right panel) shows the CALIPSO aerosol subtype: clean marine (blue), dust (yellow), polluted continental (red), clean continental (green), polluted dust (brown), and smoke (black). 


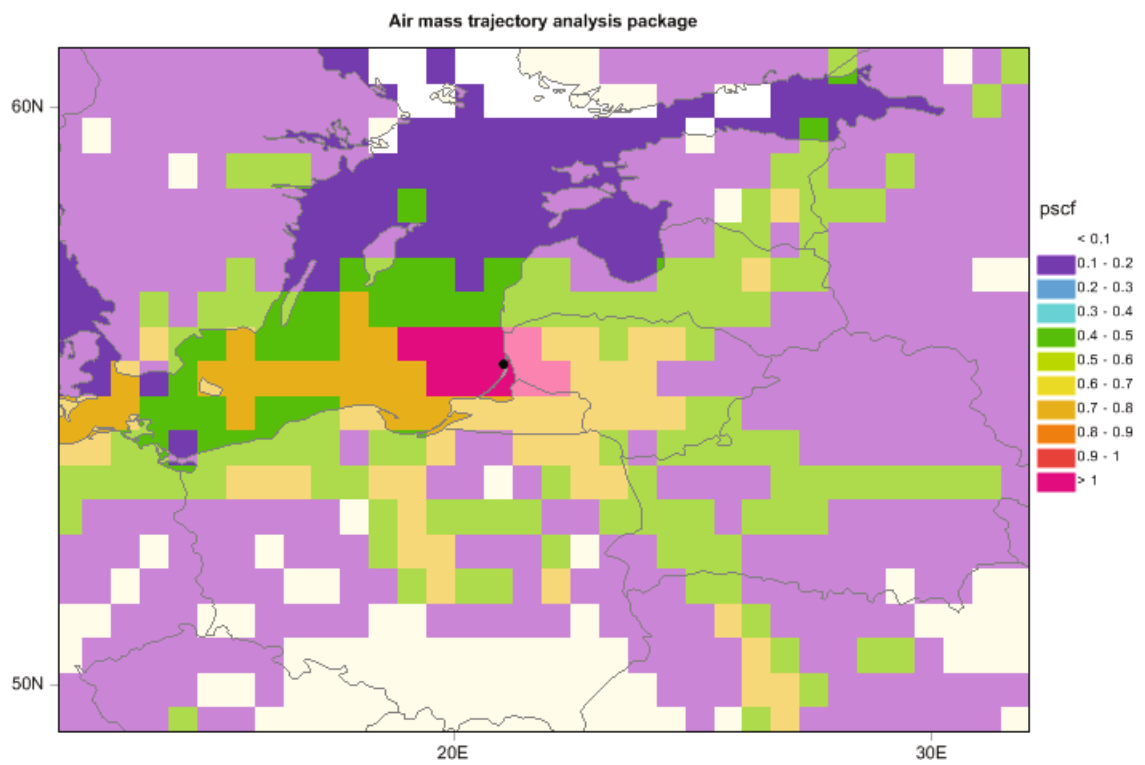

Fig. 5. The PSCF of POA factor.

The PSCF analysis (Fig. 5) combines a geographical domain with air mass back trajectories and POA factor concentrations to determine the probability that each area grid contains a source of the measured component. In Fig. 5, the high probability regions for POA are located near the sampling site between Curonian Lagoon and Baltic Sea. Measurements of organic mass fragments ( $\mathrm{m} / \mathrm{z}$ 's 60 and 73 ) show an increase in the period of air mass passing over Preila.

$\mathrm{Ng}$ et al. (2010) reported that plot of f44 versus f43 for oxygenated OA extracted from positive matrix factorization analysis fell between the two lines $(y=-0.60204 x+0.4154$ and $y=-1.8438 x+0.3319)$ shown in Fig. 6 (known as a triangle plot), and they found that such a plot converges at $f 44$ of 0.295 and $f 43$ of 0.020 as the oxidation reaction proceeds.

In our study, the plots of $f 44$ versus $f 43$ for Preila locate around the middle during 14-15 March and the bottom of the triangle with small variation during vegetation-burning episode (9-10 March). This indicates that the extent of oxidation reactions during the high OA concentration period was relatively constant. A factor with $f 44$ lower than 0.06 and $f 43$ higher than 0.03 (semi-volatile fraction of oxidised organic aerosol (OOA)) was dominant. It was estimated that the maximum ratio of $\mathrm{m} / \mathrm{z} 44$ to organics was approximately 0.1 after long-range transport during vegetation burning episode. Several studies have shown this ratio to be 0.1-0.2 in urban and remote areas, respectively (Takami et al. 2007, Takegawa et al. 2006). Ratios of $m / z 44$ 


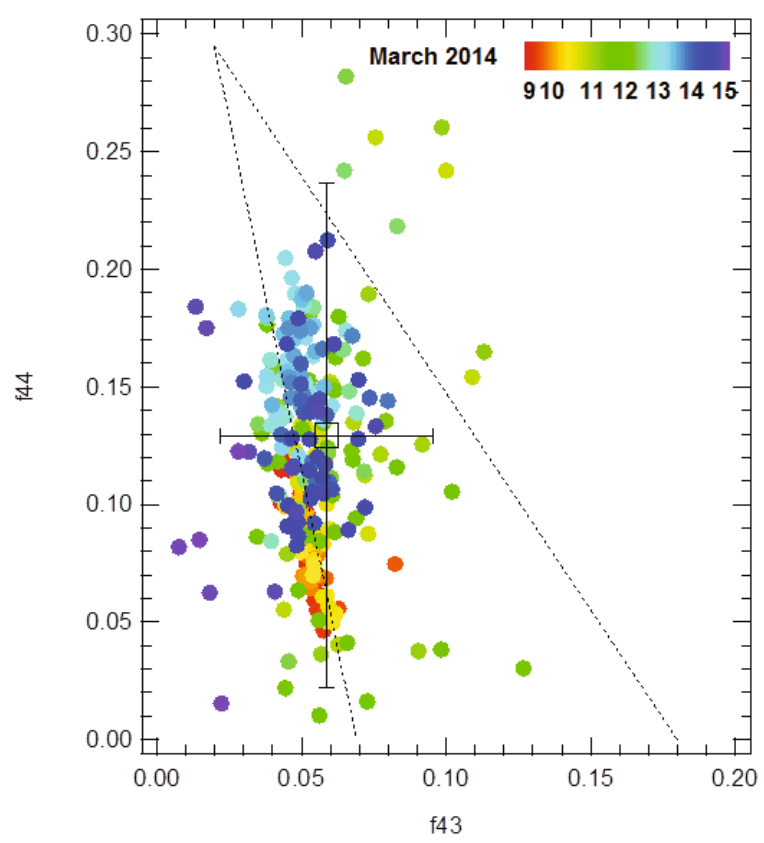

Fig. 6. The fractional signals $f 43$ and $f 44$ as a function of time during the study.

to organics measured in laboratory chambers (Bahreini et al. 2005) showed ratios of $0.04-0.07,0.04-0.08$, and 0.15 for the ozonolysis of cyclic alkenes, the ozonolysis of terpenes, and the photo-oxidation of m-xylene, respectively. The same ratio for the photo-oxidation of aromatic hydrocarbons was found to be $0.06-0.17$ by Sato et al. (2010). According to Heringa et al. (2011) the presence of wood-burning primary OA and its aging secondary organic aerosol (SOA) are found at the left edge of the triangle. It should be noted that $f 44$ values of the ACSM in comparison with $f 44$ from AMS studies can show an unresolved artefact at $f 44$ in the ACSMs (Fröhlich et al. 2015). The average organic matter to organic carbon OM/OC was found to be 2.1 which is characteristic of a remote background. For comparison, at the remote background site Finokalia it was found to be 2.4, which is in good agreement with the value of 2.2 found by Hildebrandt et al. (2010) and the value of 2.1 (Sciare et al. 2005). These increased high values of OM/OC reflect the highly oxidized nature of organic aerosol, which is highly oxidised during the early spring vegetation burning.

The CWT plot of $\mathrm{Org}^{+}, \mathrm{NO}_{3}{ }^{-}, \mathrm{SO}_{4}{ }^{2-}, \mathrm{HN}_{4}{ }^{+}, \mathrm{Cl}^{-}$, and $\mathrm{BC}$ in Fig. 7 highlighted major source areas affecting concentration variations at Preila. Dark red areas have CWTs $\geq 90$ th percentile and represent potential major source area emissions, whereas the light blue areas have CWTs $\leq 10$ th percentile, 

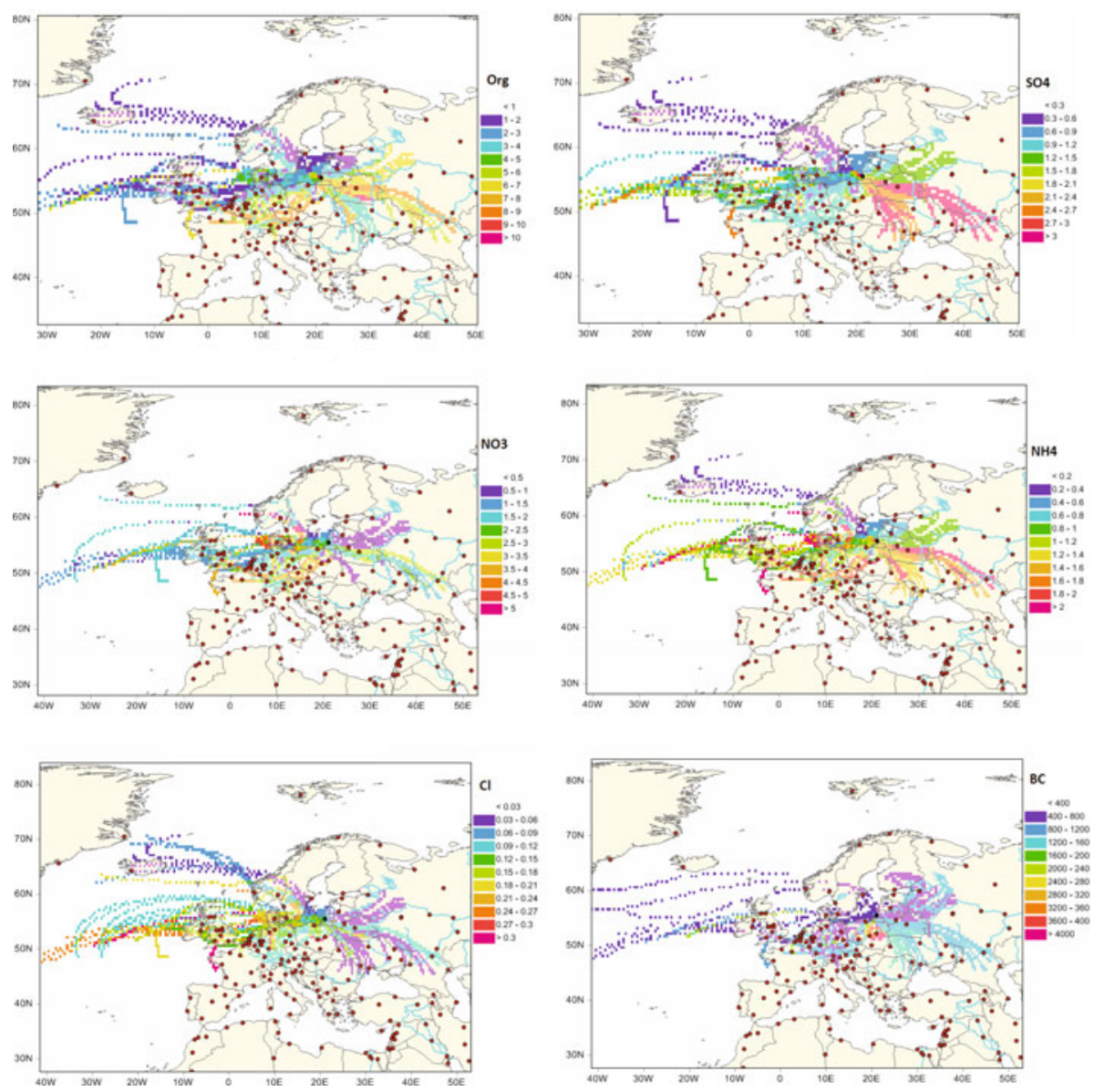

Fig. 7. CWT map for $\mathrm{Org}^{+}, \mathrm{NO}_{3}^{-}, \mathrm{SO}_{4}{ }^{2-}, \mathrm{NH}_{4}^{+}, \mathrm{Cl}^{-}\left(\right.$in $\mu \mathrm{g} \mathrm{m}^{-3}$ ) and $\mathrm{BC}$ (in $\mathrm{ng} \mathrm{m}^{-3}$ ), major source areas are dark red-shaded $(\leq 90$ th percentile of study CWTs); nonsources areas are light blue-shaded ( $\leq 10$ th percentile of study CWTs).

representing weak source areas. The moderate source areas are highlighted in green and have median CWTs during the study period. It is evident that CWTs indicate that the major source areas of vegetation burning are potentially in north-eastern Poland, and in some areas of Kaliningrad.

Air masses reaching Preila from the west have already passed over highly industrialized regions in western Europe, namely Belgium, the Netherlands, southern England, and western Germany. This area has the highest population density in Europe. The $\mathrm{BC}$ and $\mathrm{NO}_{3}{ }^{-}$concentrations significantly increase when the air masses pass above Poland. In Europe, residential wood combustion is the largest anthropogenic source of organic aerosol (Kulmala 

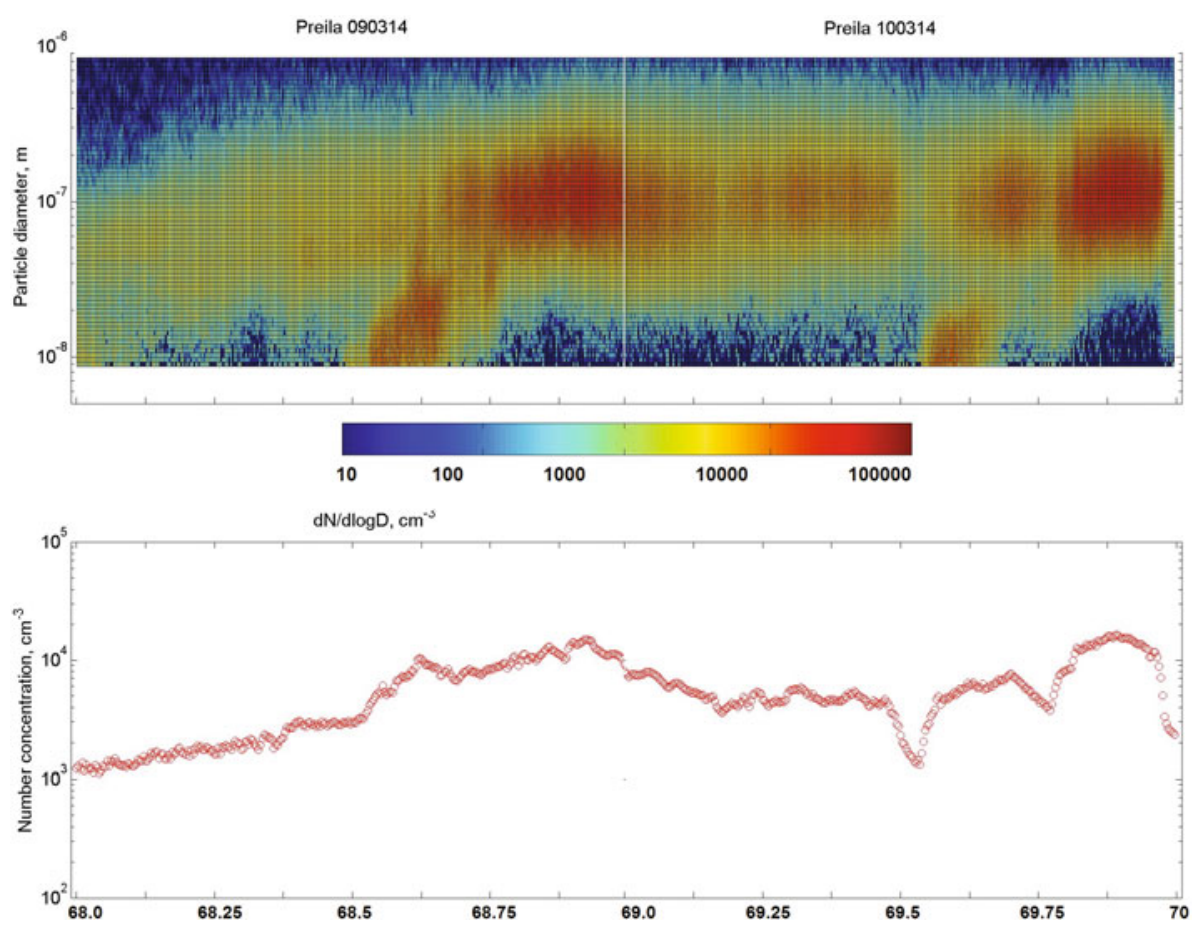

Fig. 8. New particle formation event in Preila site on 9 March 2014: particle size distribution data as a surface plot. The measured ambient particle number size distributions are fitted and parameterised by a multiple $\log$-normal distribution $(d N / d \log D p$ with units of $\mathrm{cm}^{-3}$ ).

et al. 2011). The CWT map for $\mathrm{SO}_{4}{ }^{2-}$ showed an influence of the grassfire events on possible new particle formation event due to increased concentration of sulphate. The map shows the major source area located in the east of the measurement site, in southern Belarus, Ukraine, and eastern Russia. Therefore, during the intensive grass burning episode, consecutive new particle formation (NPF) episodes were observed. Figure 8 and Table 2 exhibit the temporal evolutions of meteorological parameters and NPF characteristics.

The observed NPF could be attributed to the grass burning and secondary biomass burning product transformation, i.e., gases released by fires together with primary particles (Pratt et al. 2011) could undergo oxidation in the atmosphere to form lower volatility compounds, which condense to form secondary organic aerosol and contribute to an increase in particle number concentration (Fig. 8) (Kroll and Seinfeld 2008). At 13:00, there is a significant new particle formation on 9 and 10 March, followed by subsequent 
Table 2

Characteristics of nucleation rates, ACSM data, and associated meteorological parameters observed during nucleation (mean formation rate $0.6 \mathrm{~cm}^{-3} \mathrm{~s}^{-1}$ ) during grass burning events

\begin{tabular}{|c|c|c|c|c|c|}
\hline Parameters & Mean & Median & SD & Min & Max \\
\hline Number concentration $\left[\mathrm{cm}^{-3}\right]$ & 5960 & 5110 & 3820 & 1120 & 16230 \\
\hline Surface area $\left[\mu \mathrm{m}^{2} \mathrm{~cm}^{-3}\right]$ & 344.1 & 307.7 & 271.4 & 15.3 & 1187 \\
\hline Volume $\left[\mu \mathrm{m}^{3} \mathrm{~cm}^{-3}\right]$ & 14.89 & 13.56 & 11.02 & 0.38 & 50.71 \\
\hline Pressure $[\mathrm{hPa}]$ & 1025 & 1024 & 10 & 1020 & 1028 \\
\hline Air temperature $\left[{ }^{\circ} \mathrm{C}\right]$ & 10.1 & 8.0 & 3.6 & 3.4 & 13.4 \\
\hline Relative humidity [\%] & 62.0 & 60.5 & 18.4 & 45.0 & 92.0 \\
\hline Wind speed $\left[\mathrm{m} \mathrm{s}^{-1}\right]$ & 1.8 & 1.6 & 0.8 & 0.5 & 3.1 \\
\hline Wind direction $[\mathrm{deg}]$ & 209 & 208 & 34 & 135 & 286 \\
\hline Incoming radiation $\left[\mathrm{W} \mathrm{m}^{-2}\right]$ & 290 & 256 & 146 & 190 & 371 \\
\hline Org. $\left[\mu \mathrm{g} \mathrm{m}^{-3}\right]$ & 11.45 & 9.9 & 9.75 & 0.25 & 39.3 \\
\hline $\mathrm{SO}_{4}^{2-}\left[\mu \mathrm{g} \mathrm{m}^{-3}\right]$ & 1 & 1 & 0.6 & 0.02 & 2.3 \\
\hline $\mathrm{NO}_{3}^{-}\left[\mu \mathrm{g} \mathrm{m}^{-3}\right]$ & 3.25 & 3.15 & 2.4 & 0.05 & 8.9 \\
\hline $\mathrm{NH}_{4}^{+}\left[\mu \mathrm{g} \mathrm{m}^{-3}\right]$ & 1.35 & 1.3 & 0.85 & 0.05 & 3.1 \\
\hline $\mathrm{Cl}^{-}\left[\mu \mathrm{g} \mathrm{m}^{-3}\right]$ & 0.55 & 0.25 & 0.65 & 0 & 2.7 \\
\hline
\end{tabular}

growth during the next three hours. The total particle number concentration increased up to $13000 \pm 600 \mathrm{~cm}^{-3}$, which was extremely higher than the mean observations in this area $\left(2650 \pm 850 \mathrm{~cm}^{-3}\right)$ and is comparable only with spring concentration maxima $\left(13000 \pm 980 \mathrm{~cm}^{-3}\right)$ (Byčenkienè et al. 2013). Meanwhile, the diurnal pattern of wind direction was observed mainly coming from the SSW (190-215 degrees) with slightly higher speed in the daytime (2-3 $\left.\mathrm{m} \mathrm{s}^{-1}\right)$ and decreasing at night. The mean temperature (T) and relative humidity $(\mathrm{RH})$ were $10^{\circ} \mathrm{C}$ and $62 \%$, respectively, on NPF event days, which are higher than that the values on non-event days $\left(5^{\circ} \mathrm{C}\right.$ and $77 \%$ ). This result is consistent with the theory that lower $\mathrm{RH}$ is favourable for the enhancement of atmospheric nucleation (Hamed et al. 2007). The mean wind speed on NPF event days was slightly higher $\left(1.8 \mathrm{~m} \mathrm{~s}^{-1}\right)$ than that on non-event days $\left(1.3 \mathrm{~m} \mathrm{~s}^{-1}\right)$, which is favourable to the dilution of the pollutants. The most striking difference between typical observed NPF events (Kulmala and Kerminen 2008) is imprinted in the aerosol size distribution and number concentration when stable accumulation mode particle existed in the aged plume (Fig. 8). The nucleated particles grew in size and reached the detection size limit of the instrument at 12:30, which overlapped with the distribution of particles from grass burning emissions. The secondary parti- 
cles were mixed with the existed primary accumulation mode particles which is an indication that the source region for nucleation mode aerosol is further away from the measurement point. Larger particles could decrease the number of fresh particles due to coagulation on their surface (Kulmala et al. 2001).

The high loading of preexisting particles in the atmosphere, caused by local grass fires, may have suppressed the occurrence of NPF during most polluted days. The NPF events occurred mainly in the afternoon, which is associated with high $\mathrm{SO}_{\mathrm{x}}$. $\mathrm{SO}_{4}{ }^{2-}$ contribution to secondary organic aerosol can be significant during biomass burning. Similarly, at the same site Ulevičius et al. (2002) observed nucleation events on days when the average daily concentrations of $\mathrm{SO}_{2}$ were two to three times higher than the average monthly concentrations. Wang et al. (2013) studies in new particle formation in the presence of a strong biomass burning episode at downtown rural site in Pearl River Delta (China) found that organics and sulphates are the major components in PM1, accounting for 42 and $35 \%$ of the mass concentration, respectively. Similar trends were reported by Reid et al. (2005). They have investigated, in general, fresh smoke particles, primarily in the submicron size range, which have been found to consist of $\sim 80 \%$ organics, $\sim 5-9 \%$ black carbon, and $\sim 12-15 \%$ inorganics.

\section{CONCLUSIONS}

We have studied air pollution transport climatology from the Preila background measurement site point of view. The influence of air masses on the organic and inorganic aerosol concentrations measured at the Preila sampling site has been analysed. By classifying the source regions of air masses in sectors it was possible to establish the dependence of the aerosol chemical composition on the type of air mass. The CWT maps show a great influence of the Russia, Belarus, Ukraine, and Poland areas to BC and PM concentration in spring. The most polluted clusters 1 and 4 originated from the vegetation burning occurred in northern Poland, Kaliningrad enclave and southeast Belarus, indicating that it is an important transport pathway determining high PM concentrations at the Preila site. Moreover, the CWT analysis suggests that the semivolatile OA particles emitted from vegetation combustion were mainly long-range transported from Kaliningrad. About half of the potentially semi-volatile organic aerosol particles were internally mixed with more oxidised particles and were presumed to be transported mainly from Russia, Belarus, and Ukraine. The observed NPFs were attributed to the grass burning and secondary biomass burning product transformation and contributed to an increase in particle number concentration. 
Acknowledgments. The research leading to these results has received funding from Lithuanian-Swiss cooperation programme to reduce economic and social disparities within the enlarged EU under project agreement No. CH-3-ŠMM-01/08.

\section{References}

Abdalmogith, S.S., and R.M. Harrison (2005), The use of trajectory cluster analysis to examine the long-range transport of secondary inorganic aerosol in the UK, Atmos. Environ. 39, 35, 6686-6695, DOI: 10.1016/j.atmosenv.2005. 07.059 .

Amiridis, V., E. Giannakaki, D.S. Balis, E. Gerasopoulos, I. Pytharoulis, P. Zanis, S. Kazadzis, D. Melas, and C. Zerefos (2010), Smoke injection heights from agricultural burning in Eastern Europe as seen by CALIPSO, Atmos. Chem. Phys. 10, 23, 11567-11576, DOI: 10.5194/acp-10-11567-2010.

Bahreini, R., M.D. Keywood, N.L. Ng, V. Varutbangkul, S. Gao, R.C. Flagan, J.H. Seinfeld, D.R. Worsnop, and J.L. Jimenez (2005), Measurements of secondary organic aerosol from oxidation of cycloalkenes, terpenes, and $\mathrm{m}$ xylene using an aerodyne aerosol mass spectrometer, Environ. Sci. Technol. 39, 15, 5674-5688, DOI: 10.1021/es048061a.

Beverland, I.J., T. Tunes, M. Sozanska, R.A. Elton, R.M. Agius, and M.R. Heal (2000), Effect of long-range transport on local PM10 concentrations in the UK, Int. J. Environ. Heal. Res. 10, 3, 229-238, DOI: 10.1080/ 09603120050127176.

Blum, U., K.H. Fricke, K.P. Müller, J. Siebert, and G. Baumgarten (2005), Longterm lidar observations of polar stratospheric clouds at Esrange in northern Sweden, Tellus B 57, 5, 412-422, DOI: 10.1111/j.1600-0889.2005.00161.x.

Bond, T.C., S.J. Doherty, D.W. Fahey, P.M. Forster, T. Berntsen, B.J. DeAngelo, M.G. Flanner, S. Ghan, B. Kärcher, D. Koch, S. Kinne, Y. Kondo, P.K. Quinn, M.C. Sarofim, M.G. Schultz, M. Schulz, C. Venkataraman, H. Zhang, S. Zhang, N. Bellouin, S.K. Guttikunda, P.K. Hopke, M.Z. Jacobson, J.W. Kaiser, Z. Klimont, U. Lohmann, J.P. Schwarz, D. Shindell, T. Storelvmo, S.G. Warren, and C.S. Zender (2013), Bounding the role of black carbon in the climate system: A scientific assessment, J. Geophys. Res. 118, 11, 5380-5552, DOI: 10.1002/jgrd.50171.

Byčenkienè, S., V. Ulevičius, V. Dudoitis, and J. Pauraitė (2013), Identification and characterization of black carbon aerosol sources in the East Baltic region, Adv. Meteorol. 2013, DOI: 10.1155/2013/380614.

Byčenkienè, S., V. Dudoitis, and V. Ulevičius (2014), The use of trajectory cluster analysis to evaluate the long-range transport of black carbon aerosol in the 
South-Eastern Baltic region, Adv. Meteorol. 2014, DOI: 10.1155/2014/ 137694.

Dall'Osto, M., S. Hellebust, R.M. Healy, I.P. O’Connor, I. Kourtchev, J.-R. Sodeau, J. Ovadnevaite, D. Ceburnis, C.-D. O’Dowd, and J.-C. Wenger (2014), Apportionment of urban aerosol sources in Cork (Ireland) by synergistic measurement techniques, Sci. Total Environ. 493, 197-208, DOI: 10.1016/ j.scitotenv.2014.05.027.

Draxler, R.R., and G.D. Rolph (2014), HYSPLIT (HYbrid Single-Particle Lagrangian Integrated Trajectory) model access via NOAA ARL READY website, NOAA Air Resources Laboratory, Silver Spring, USA, http://ready.arl. noaa.gov/HYSPLIT.php.

Du, S.Y., and L.A. Rodenburg (2007), Source identification of atmospheric PCBs in Philadelphia/Camden using positive matrix factorization followed by the potential source contribution function, Atmos. Environ. 41, 38, 8596-8608, DOI: 10.1016/j.atmosenv.2007.07.042.

Fröhlich, R., V. Crenn, A. Setyan, C.A. Belis, F. Canonaco, O. Favez, V. Riffault, J.G. Slowik, W. Aas, M. Aijälä, A. Alastuey, B. Artiñano, N. Bonnaire, C. Bozzetti, M. Bressi, C. Carbone, E. Coz, P.L. Croteau, M.J. Cubison, J.K. Esser-Gietl, D.C. Green, V. Gros, L. Heikkinen, H. Herrmann, J.T. Jayne, C.R. Lunder, M.C. Minguillón, G. Močnik, C.D. O’Dowd, J. Ovadnevaite, E. Petralia, L. Poulain, M. Priestman, A. Ripoll, R. SardaEstève, A. Wiedensohler, U. Baltensperger, J. Sciare, and A.S.H. Prévôt (2015), ACTRIS ACSM intercomparison - Part 2: Intercomparison of ME-2 organic source apportionment results from 15 individual, co-located aerosol mass spectrometers, Atmos. Meas. Tech. Discuss. 8, 1559-1613, DOI: $10.5194 /$ amtd-8-1559-2015.

Gildemeister, A.E., P.K. Hopke, and E. Kim (2007), Sources of fine urban particulate matter in Detroit, MI, Chemosphere 69, 7, 1064-1074, DOI: 10.1016/ j.chemosphere.2007.04.027.

Goode, J.G., R.J. Yokelson, R.A. Susott, and D.E. Ward (1999), Trace gas emissions from laboratory biomass fires measured by open-path Fourier transform infrared spectroscopy: Fires in grass and surface fuels, J. Geophys. Res. 104, D17, 21237-21245, DOI: 10.1029/1999JD900360.

Hamed, A., J. Joutsensaari, S. Mikkonen, L. Sogacheva, M. Dal Maso, M. Kulmala, F. Cavalli, S. Fuzzi, M.C. Facchini, S. Decesari, M. Mircea, K.E.J. Lehtinen, and A. Laaksonen (2007), Nucleation and growth of new particles in Po Valley, Italy, Atmos. Chem. Phys. 7, 2, 355-376, DOI: 10.5194/acp-7355-2007.

Heringa, M.F., P.F. DeCarlo, R. Chirico, T. Tritscher, J. Dommen, E. Weingartner, R. Richter, G. Wehrle, A.S.H. Prévôt, and U. Baltensperger (2011), Investigations of primary and secondary particulate matter of different wood combustion appliances with a high-resolution time-of-flight aerosol mass spectrometer, Atmos. Chem. Phys. 11, 12, 5945-5957, DOI: 10.5194/acp11-5945-2011. 
Hildebrandt, L., E. Kostenidou, N. Mihalopoulos, D.R. Worsnop, N.M. Donahue, and S.N. Pandis (2010), Formation of highly oxygenated organic aerosol in the atmosphere: Insights from the Finokalia Aerosol Measurement Experiments, Geophys. Res. Lett. 37, 23, L23801, DOI: 10.1029/2010GL045193.

Hoh, E., and R.A. Hites (2004), Sources of toxaphene and other organochlorine pesticides in North America as determined by air measurements and potential source contribution function analyses, Environ. Sci. Technol. 38, 15, 41874194, DOI: 10.1021/es0499290.

IPCC (2013), Climate Change 2013: The Physical Science Basis, Working Group I Contribution to the 5th Assessment Report, Intergovernmental Panel on Climate Change, Bern, Switzerland.

Jeong, U., J. Kim, H. Lee, J. Jung, Y.J. Kim, C.H. Song, and J.H. Koo (2011), Estimation of the contributions of long range transported aerosol in East Asia to carbonaceous aerosol and PM concentrations in Seoul, Korea using highly time resolved measurements: a PSCF model approach, J. Environ. Monit. 13, 7, 1905-1918, DOI: 10.1039/c0em00659a.

Kabashnikov, V.P., A.P. Chaikovsky, T.L. Kucsera, and N.S. Metelskaya (2011), Estimated accuracy of three common trajectory statistical methods, Atmos. Environ. 45, 31, 5425-5430, DOI: 10.1016/j.atmosenv.2011.07.006.

Kroll, J.H., and J.H. Seinfeld (2008), Chemistry of secondary organic aerosol: Formation and evolution of low-volatility organics in the atmosphere, Atmos. Environ. 42, 16, 3593-3624, DOI: 10.1016/j.atmosenv.2008.01.003.

Kulmala, M., and V.M. Kerminen (2008), On the formation and growth of atmospheric nanoparticles, Atmos. Res. 90, 2-4, 132-150, DOI: 10.1016/ j.atmosres.2008.01.005.

Kulmala, M., M. Dal Maso, J.M. Mäkelä, L. Pirjola, M. Väkevä, P. Aalto, P. Miikkulainen, K. Hämeri, and C.D. O'Dowd (2001), On the formation, growth and composition of nucleation mode particles, Tellus B 53, 4, 479-490, DOI: 10.1034/j.1600-0889.2001.530411.x.

Kulmala, M., A. Asmi, H.K. Lappalainen, U. Baltensperger, J.-L. Brenguier, M.C. Facchini, H.-C. Hansson, Ø. Hov, C.D. O’Dowd, U. Pöschl, A. Wiedensohler, R. Boers, O. Boucher, G. de Leeuw, H.A.C. Denier van der Gon, J. Feichter, R. Krejci, P. Laj, H. Lihavainen, U. Lohmann, G. McFiggans, T. Mentel, C. Pilinis, I. Riipinen, M. Schulz, A. Stohl, E. Swietlicki, E. Vignati, C. Alves, M. Amann, M. Ammann, S. Arabas, P. Artaxo, H. Baars, D.C.S. Beddows, R. Bergström, J.P. Beukes, M. Bilde, J.F. Burkhart, F. Canonaco, S.L. Clegg, H. Coe, S. Crumeyrolle, B. D’Anna, S. Decesari, S. Gilardoni, M. Fischer, A.M. Fjaeraa, C. Fountoukis, C. George, L. Gomes, P. Halloran, T. Hamburger, R.M. Harrison, H. Herrmann, T. Hoffmann, C. Hoose, M. Hu, A. Hyvärinen, U. Hõrrak, Y. Iinuma, T. Iversen, M. Josipovic, M. Kanakidou, A. Kiendler-Scharr, A. Kirkevåg, G. Kiss, Z. Klimont, P. Kolmonen, M. Komppula, J.-E. Kristjánsson, L. Laakso, A. Laaksonen, L. Labonnote, V.A. Lanz, K.E.J. Lehtinen, L.V. Rizzo, R. Makkonen, H.E. Manninen, G. McMeeking, 
J. Merikanto, A. Minikin, S. Mirme, W.T. Morgan, E. Nemitz, D. O’Donnell, T.S. Panwar, H. Pawlowska, A. Petzold, J.J. Pienaar, C. Pio, C. Plass-Duelmer, A.S.H. Prévôt, S. Pryor, C.L. Reddington, G. Roberts, D. Rosenfeld, J. Schwarz, Ø. Seland, K. Sellegri, X.J. Shen, M. Shiraiwa, H. Siebert, B. Sierau, D. Simpson, J.Y. Sun, D. Topping, P. Tunved, P. Vaattovaara, V. Vakkari, J.P. Veefkind, A. Visschedijk, H. Vuollekoski, R. Vuolo, B. Wehner, J. Wildt, S. Woodward, D.R. Worsnop, G.-J. van Zadelhoff, A.A. Zardini, K. Zhang, P.G. van Zyl, V.-M. Kerminen, K.S. Carslaw, and S.N. Pandis (2011), General overview: European integrated project on Aerosol Cloud Climate and Air Quality Interactions (EUCAARI) - integrating aerosol research from nano to global scales, Atmos. Chem. Phys. 11, 24, 13061-13143, DOI: 10.5194/acp-11-13061-2011.

Labonne, M., F.-M. Bréon, and F. Chevallier (2007), Injection height of biomass burning aerosols as seen from a spaceborne lidar, Geophys. Res. Lett. 34, 11, L11806, DOI: 10.1029/2007GL029311.

Mauderly, J.L., and J.C. Chow (2008), Health effects of organic aerosols, Inhal. Toxicol. 20, 3, 257-288, DOI: 10.1080/08958370701866008.

Ng, N.L., M.R. Canagaratna, Q. Zhang, J.L. Jimenez, J. Tian, I.M. Ulbrich, J.H. Kroll, K.S. Docherty, P.S. Chhabra, R. Bahreini, S.M. Murphy, J.H. Seinfeld, L. Hildebrandt, N.M. Donahue, P.F. DeCarlo, V.A. Lanz, A.S.H. Prévôt, E. Dinar, Y. Rudich, and D.R. Worsnop (2010), Organic aerosol components observed in Northern Hemispheric datasets from Aerosol Mass Spectrometry, Atmos. Chem. Phys. 10, 10, 4625-4641, DOI: 10.5194/acp-10-4625-2010.

Ng, N.L., S.C. Herndon, A. Trimborn, M.R. Canagaratna, P.L. Croteau, T.B. Onasch, D. Sueper, D.R. Worsnop, Q. Zhang, Y.L. Sun, and J.T. Jayne (2011), An Aerosol Chemical Speciation Monitor (ACSM) for routine monitoring of the composition and mass concentrations of ambient aerosol, Aerosol Sci. Technol. 45, 7, 780-794, DOI: 10.1080/02786826.2011. 560211.

Ovadnevaitè, J., K. Kvietkus, and A. Maršalka (2006), 2002 summer fires in Lithuania: Impact on the Vilnius city air quality and the inhabitants health, Sci. Total Environ. 356, 1-3, 11-21, DOI: 10.1016/j.scitotenv.2005.04.013.

Paatero, P. (1997), Least squares formulation of robust non-negative factor analysis, Chemometr. Intell. Lab. Syst.. 37, 1, 23-35, DOI: 10.1016/S0169-7439(96) 00044-5.

Pratt, K.A., S.M. Murphy, R. Subramanian, P.J. DeMott, G.L. Kok, T. Campos, D.C. Rogers, A.J. Prenni, A.J. Heymsfield, J.H. Seinfeld, and K.A. Prather (2011), Flight-based chemical characterization of biomass burning aerosols within two prescribed burn smoke plumes, Atmos. Chem. Phys. 11, 24, 12549-12565, DOI: 10.5194/acp-11-12549-2011.

Putaud, J.P., F. Raes, R. van Dingenen, E. Brüggemann, M.C. Facchini, S. Decesari, S. Fuzzi, R. Gehrig, C. Hüglin, P. Laj, G. Lorbeer, W. Maenhaut, N. Mihalopoulos, K. Müller, X. Querol, S. Rodriguez, J. Schneider, G. Spindler, 
H. ten Brink, K. Tørseth, and A. Wiedensohler (2004), A European aerosol phenomenology - 2: Chemical characteristics of particulate matter at kerbside, urban, rural and background sites in Europe, Atmos. Environ. 38, 16, 2579-2595, DOI: 10.1016/j.atmosenv.2004.01.041.

Putaud, J.P., R. van Dingenen, A. Alastuey, H. Bauer, W. Birmili, J. Cyrys, H. Flentje, S. Fuzzi, R. Gehrig, H.C. Hansson, R.M. Harrison, H. Herrmann, R. Hitzenberger, C. Hüglin, A.M. Jones, A. Kasper-Giebl, G. Kiss, A. Kousa, T.A.J. Kuhlbusch, G. Löschau, W. Maenhaut, A. Molnar, T. Moreno, J. Pekkanen, C. Perrino, M. Pitz, H. Puxbaum, X. Querol, S. Rodriguez, I. Salma, J. Schwarz, J. Smolik, J. Schneider, G. Spindler, H. ten Brink, J. Tursic, M. Viana, A. Wiedensohler, and F. Raes (2010), A European aerosol phenomenology - 3: Physical and chemical characteristics of particulate matter from 60 rural, urban, and kerbside sites across Europe, Atmos. Environ. 44, 10, 1308-1320, DOI: 10.1016/j.atmosenv.2009.12.011.

Reid, J.S., R. Koppmann, T.-F. Eck, and D.P. Eleuterio (2005), A review of biomass burning emissions. Part II: Intensive physical properties of biomass burning particles, Atmos. Chem. Phys. 5, 3, 799-825, DOI: 10.5194/acp-5-799-2005.

Rizzo, M.J., and P.A. Scheff (2007), Fine particulate source apportionment using data from the USEPA speciation trends network in Chicago, Illinois: Comparison of two source apportionment models, Atmos. Environ. 41, 29, 62766288, DOI: 10.1016/j.atmosenv.2007.03.055.

Saarikoski, S., M. Sillanpää, M. Sofiev, H. Timonen, K. Saarnio, K. Teinilä, A. Karppinen, J. Kukkonen, and R. Hillamo (2007), Chemical composition of aerosols during a major biomass burning episode over northern Europe in spring 2006: Experimental and modelling assessments, Atmos. Environ. 41, 17, 3577-3589, DOI: 10.1016/j.atmonsenv.2006.12.053.

Salvador, P., B. Artiñano, D.G. Alonso, X. Querol, and A. Alastuey (2004), Identification and characterisation of sources of $\mathrm{PM}_{10}$ in Madrid (Spain) by statistical methods, Atmos. Environ. 38, 3, 435-447, DOI: 10.1016/j.atmosenv. 2003.09.070.

Sato, K., A. Takami, T. Isozaki, T. Hikida, A. Shimono, and T. Imamura (2010), Mass spectrometric study of secondary organic aerosol formed from the photo-oxidation of aromatic hydrocarbons, Atmos. Environ. 44, 8, 10801087, DOI: 10.1016/j.atmosenv.2009.12.013.

Sciare, J., K. Oikonomou, H. Cachier, N. Mihalopoulos, M.O. Andreae, W. Maenhaut, and R. Sarda-Estève (2005), Aerosol mass closure and reconstruction of the light scattering coefficient over the Eastern Mediterranean Sea during the MINOS campaign, Atmos. Chem. Phys. 5, 2253-2265, DOI: 10.5194/ acp-5-2253-2005.

Sillanpää, M., A. Frey, R. Hillamo, A.S. Pennanen, and R.O. Salonen (2005), Organic, elemental and inorganic carbon in particulate matter of six urban environments in Europe, Atmos. Chem. Phys. 5, 11, 2869-2879, DOI: 10.5194/acp-5-2869-2005. 
Takami, A., T. Miyoshi, A. Shimono, N. Kaneyasu, S. Kato, Y. Kajii, and S. Hatakeyama (2007), Transport of anthropogenic aerosols from Asia and subsequent chemical transformation, J. Geophys. Res. 112, D22, D22S31, DOI: 10.1029/2006JD008120.

Takegawa, N., T. Miyakawa, Y. Kondo, J.L. Jimenez, Q. Zhang, D.R. Worsnop, and M. Fukuda (2006), Seasonal and diurnal variations of submicron organic aerosol in Tokyo observed using the Aerodyne aerosol mass spectrometer, J. Geophys. Res. 111, D11, D11206, DOI: 10.1029/2005JD006515.

Ulevičius, V., G. Mordas, and K. Plauškaitè (2002), Evolution of aerosol particle size distribution in the coastal environment: effect of relative humidity, $\mathrm{SO}_{2}$ and $\mathrm{NO}_{2}$, Environ. Chem. Phys. 24, 1, 13-17.

Ulevičius, V., S. Byčenkienė, V. Remeikis, A. Garbaras, S. Kecorius, J. Andriejauskienė, D. Jasinevičienė, and G. Mocnik (2010), Characterization of pollution events in the East Baltic region affected by regional biomass fire emissions, Atmos. Res. 98, 2-4, 190-200, DOI: 10.1016/j.atmosres.2010.03. 021.

van Dingenen, R., F. Raes, J.P. Putaud, U. Baltensperger, A. Charron, M.C. Facchini, S. Decesari, S. Fuzzi, R. Gehrig, H.C. Hansson, R.M. Harrison, C. Hüglin, A.M. Jones, P. Laj, G. Lorbeer, W. Maenhaut, F. Palmgren, X. Querol, S. Rodriguez, J. Schneider, H. ten Brink, P. Tunved, K. Tørseth, B. Wehner, E. Weingartner, A. Wiedensohler, and P. Wåhlin (2004), A European aerosol phenomenology - 1: Physical characteristic of particulate matter at kerbside, urban, rural and background sites in Europe, Atmos. Environ. 38, 16, 2561-2577, DOI: 10.1016/j.atmosenv.2004.01.040.

Virkkula, A., T. Mäkelä, R. Hillamo, T. Yli-Tuomi, A. Hirsikko, K. Hämeri, and I.K. Koponen (2007), A simple procedure for correcting loading effects of Aethalometer data, J. Air Waste Manag. Assoc. 57, 10, 1214-1222, DOI: 10.3155/1047-3289.57.10.1214.

Wang, Z.B., M. Hu, D.L. Yue, L.Y. He, X.F. Huang, Q. Yang, J. Zheng, R.Y. Zhang, and Y.H. Zhang (2013), New particle formation in the presence of a strong biomass burning episode at a downwind rural site in PRD, China, Tellus B 65, 19965, DOI: 10.3402/tellusb.v65i0.19965.

Yttri, K.E., W. Aas, A. Bjerke, J.N. Cape, F. Cavalli, D. Ceburnis, C. Dye, L. Emblico, M.C. Facchini, C. Forster, J.E. Hanssen, H.C. Hansson, S.G. Jennings, W. Maenhaut, J.P. Putaud, and K. Tørseth (2007), Elemental and organic carbon in $\mathrm{PM}_{10}$ : a one year measurement campaign within the European Monitoring and Evaluation Programme EMEP, Atmos. Chem. Phys. 7, 22, 5711-5725, DOI: 10.5194/acp-7-5711-2007.

Received 25 September 2014

Received in revised form 14 March 2015

Accepted 22 April 2015 